\title{
Lifespan Development of Word Use from Early Childhood to Old Age
}

\author{
YoonKyoung Lee ${ }^{\mathrm{a}}$, Jieun Choi ${ }^{\mathrm{b}}$, Ji Hye Yoon ${ }^{\mathrm{a}}$, Yu-Seop Kim, Jun Sang Min ${ }^{\mathrm{b}}$, Jisu Kim \\ ${ }^{a}$ Division of Speech Pathology and Audiology, Hallym University, Chuncheon, Korea \\ ${ }^{b}$ Department of Speech-Language Pathology and Audiology, Graduate School of Hallym University, Chuncheon, Korea \\ 'Department of Convergence Software, Hallym University, Chuncheon, Korea
}

\author{
Correspondence: YoonKyoung Lee, $\mathrm{PhD}$ \\ Division of Speech Pathology and Audiology, \\ Hallym University, 1 Hallimdaehak-gil, Chunchon \\ 24252, Korea \\ Tel: +82-33-248-2219 \\ Fax: +82-33-256-3420 \\ E-mail: ylee@hallym.ac.kr
}

Received: October 5, 2017

Revised: December 6, 2017

Accepted: December 12, 2017

This work was supported by the Hallym Leading Research Group Support Program of 2017 (No. HRF-LGR-2017-0002)

We thank Yewon Yang, Seung A Oh, Jin Ju Choi, \& Weon Kyeong Hong for their assistance in collecting and analyzing the data.

\begin{abstract}
Objectives: This study aimed to examine lifelong lexical development from early childhood to old age. Methods: Typically developing children, adolescents, young adults, older adults, and elderly adults $(\mathrm{N}=120)$ participated in the study. The participants were classified to six age groups; early childhood, late childhood, adolescent, young adult, older adult, and elderly whose mean ages were $5,10,16,28,53$, and 67 years, respectively. Language samples of the participants were taken during semi-structured conversation with an examiner. Total number of word (TNW), number of different word (NDW), and type-token ratio (TTR), depending on word class, were measured. Results: TNW and NDW increased from early childhood to adolescence significantly, then decreased in the age groups after young adulthood. TTR decreased gradually from early childhood to adolescence, but was consistent from young adults to the elderly. There were differences in TNW, NDW, and TTR according to word class. Noun, verb, adverb, and adjective usage increased from early childhood to adolescence significantly, and then slightly decreased in young adults and was maintained by the elderly. TNW of pronoun gradually increased from adolescence to old age, and TNW and NDW also increased during adulthood. The TTR of early and later childhood was higher than .5, but less than .4 in adolescents and young adults. Discriminant analysis showed adverb TNW, verb NDW, adjective TNW, and adverb NDW were good discriminators between the age groups. Conclusion: The results provide useful implications for understanding lifelong language development from preschoolers to the elderly.
\end{abstract}

Keywords: Lifelong language development, Lexical development, Word use, TNW, NDW, TTR
전통적으로 언어발달은 첫 낱말을 산출하기 시작하면서 언어발 달이 급격하게 이루어지는 초기 아동기 및 초기 아동기를 중심으 로 연구되어 왔다. 그러나 언어발달에 대한 관심이 주로 통사나 의 미 영역 발달에 집중되어 있던 것에서 벗어나 화용이나 담화 영역 의 발달에 대한 관심이 증가하고, 구어(oral language) 영역에 국한 되었던 언어발달이 문어(written language) 발달까지 확장됨에 따 라 아동기 이후의 언어발달에 대한 관심이 증가하게 되었다(Nippold, 2007).

이와 더불어 발달심리학에서 대두된 '전생애 발달(life span development)' 이론도 아동기 이후의 언어발달에 대한 관심을 증가시
키는 데에 영향을 주었다(De Bot \& Schrauf, 2010; Gerstenberg \& Voeste, 2015). 전생애 발달 이론은 인간의 발달이 생애 전반에 걸 쳐 진행된다는 것을 강조하는 이론으로(Baltes, 1987) 인간의 발달 이 태내에서 난자와 정자가 수정되는 순간부터 태어나 죽을 때까지 지속된다고 본다. 따라서 발달이 행동의 효율성이 증가하는 것은 물론 쇠퇴 또는 감소하는 방향으로도 진행될 수 있다고 간주하고, 인간 행동발달을 행동습득 중심으로 파악하던 관점에서 탈피하여 행동이 쇠퇴 또는 감소되는 변화하는 양상까지 발달적 변화에 포 함하였다. 전생애 발달 이론은 발달을 아동기에서 노년기까지의 연 속적 과정을 통해 이해하도록 관점을 확장하였으며, 각 발달시기에 
이루어지는 발달적 변화를 다른 발달단계에서의 변화와 관련하여 이해할수 있게 하였다.

아동기 이후의 언어발달에 대한 관심 증가와 더불어 관련 연구 들도 많아지고 있으나 아직까지 아동기 이후의 언어발달 연구는 대 부분 초기 아동기부터 청소년기나 성인기까지만을 포함하거나 성 인기부터 노년기까지를 대상으로 이원화되어 진행되고 있다(Ardila \& Rosselli, 1996; Burke \& Shafto, 2008; Kemper, Kynette, Rash, \& O’Brien, 1989; Kemper, Thompson, \& Marquis, 2001; Lee \& Kim, 2001; Nippold, 2000; Nippold \& Duthie, 2003; Nippold \& Sun, 2008; Nippold, Ward-Lonergan, \& Fanning, 2005). 이처럼 이 원화되어 진행되는 이유는 발달을 행동의 증가 혹은 발전의 관점 으로 보거나 혹은 감소 또는 쇠퇴를 중심으로 고려하며, 증가 혹은 쇠퇴를 연속적 과정으로 이해하지 않기 때문으로 이해된다. 앞에 서도 서술하였지만, 전생애에 걸쳐 발달적 경향을 살펴보는 것은 특정 시기의 발달적 변화를 다른 발달단계에서의 변화와 관련하여 이해할 수 있게 함으로써 더 심도 깊은 이해를 가능하게 한다.

언어발달 양상은 문법, 의미, 화용 및 담화와 같이 언어의 전반에 걸쳐 나타날 수 있으나, 그 중에서도 어휘 의미 발달은 언어발달 연 구가 아동기에 국한되어 진행되었을 때부터 생애 전반에 걸쳐 꾸준 하게 발달하는 언어영역으로 고려되어 왔다(Nippold, 2007). 더욱 이 어휘는 언어 사용에 있어 필수적 요소이며, 어휘 없이는 구문 패 턴은 물론 형태론적 구조나 말소리 패턴조차도 파악이 어려우므로 (Clark, 1995) 어휘를 중심으로 언어발달 양상을 확인하는 것은 중 요하다할수 있다.

전통적으로 어휘발달은 어휘의 양적 발달을 중심으로 보고되어 왔다. 보통 1 세를 즈음하여 첫 낱말이 산출된 이후, 2 세경에는 50 개 에서 500 개 또는 600 개의 어휘를 사용하게 되며, 매일 10 개 내외의 어휘를 추가하여 6세 정도에 이르면 14,000 개 정도의 어휘를 산출 하게 된다(Carey, 1978; as cited in Clark, 1995). 초기 아동기 이후에 는 읽기와 학교 교육이 시작됨에 따라 새롭게 노출되는 어휘량도 크게 증가하는데, 대체로 10 세 정도에는 매해 10,000 개 정도, 15 세 경에는 약 100,000 개의 새로운 낱말에 노출되며(Nagy \& Anderson, 1984) 이와 더불어 사용하는 어휘량도 함께 증가하여 대체로 성인들은 20,000 개에서 50,000 개 사이의 어휘를 사용할 것으로 추 정된다(Clark, 1995).

성인기 이후에는 언어능력이 점차 쇠퇴할 것이라는 기대와 달리 어휘능력이나 어휘 사용량은 감소하지 않고 오히려 증가하거나 유 지된다고 보고되었다. Kemper와 Sumner (2001)는 젊은 성인(연령 평균 22.8세, 범위 18-28세)과 노인(연령 평균 76.4세, 범위 63-88세) 의 표준화 검사와 구어 샘플을 분석하여 비교하였는데, 표준화 검
사로 측정된 어휘능력은 노년기가 성인기에 비해 유의하게 높았으 며, 구어 샘플에서의 어휘다양도도 높았다고 보고하였으며, Lindenberger와 Baltes (1997)도 70세 이후부터 90세까지 어휘점수가 감소하지 않고 유지되었다고 보고하였다. 그러나 대부분의 연구가 표준화된 언어검사를 이용하여 비교한 것이기 때문에 실제로 사용 하는 어휘량에 대한 것은 아니며, 자발화 분석을 통한 어휘 연구도 어휘다양도를 중심으로 보고한 것이기 때문에 실제 어휘 사용의 양적인 변화를 반영하지는 않는다.

우리나라의 경우도 여러 연령층을 대상으로 어휘 사용에 대한 연구가 진행되었으나, 구어를 중심으로 한 연구는 어린 아동(Lee, Kwon, \& Jung, 1980), 중·고등학생(Chang \& Jeon, 2008), 대학생 (Seo \& Ku, 2005) 등 특정 연령층을 대상으로 이루어진 소수 연구 에 불과하다. 이들 연구를 종합해 보면 3세부터 5 세 6 개월 사이의 아동을 대상으로 한 Lee 등(1980)은 연령에 따라 어휘 사용량이 증 가하였다고 보고하였다. 품사별로는 전체 사용된 어휘 중 명사가 절반 가까이를 차지하였고, 동사가 $25 \%$ 내외, 부사가 $10 \%-12 \%$ 정 도 사용하여 세 품사가 전체 어휘의 $85 \%-90 \%$ 정도를 차지하였다. 중고등학생을 대상으로 한 Chang과 Jeon (2008)은 전체 어휘에서 의 total number of word (TNW, 전체 어휘 수), number of different word (NDW, 다른 낱말 수), type-token ratio (TTR, 어휘다양도)만 보고했는데, 중학생에 비해 고등학생 때 TNW나 NDW는 감소하 였으나 TTR은 증가하였다고 보고하였다. 반대로 대학생을 대상으 로 한 Seo와 $\mathrm{Ku}$ (2005)는 품사별 TNW와 NDW만을 보고했는데 TNW와 NDW 모두 명사가 가장 많은 비중을 차지하였고, 그 다음 으로 동사, 부사, 대명사, 형용사 순서로 나타났다. 명사가 TNW에서 는 $36.3 \%$ 정도, $\mathrm{NDW}$ 에서는 $65 \%$ 정도를 차지하여 같은 어휘를 반 복적으로 사용하는 경향을 보였으나, 동사는 TNW에서는 $18.6 \%$, $\mathrm{NDW}$ 에서는 $13.2 \%$ 로 비교적 다양한 어휘들을 사용하는 경향을 보였다. 형용사의 경우도 TNW와 NDW의 비율이 거의 비슷하여 다양한 어휘를 사용하는 경향을 보였으나, 부사와 대명사는 TNW 와 NDW의 비율차이가 커서 동일한 어휘를 반복적으로 사용하는 경향을 보였다.

현재까지 이루어진 연구를 보면, 국내외를 막론하고 어휘 사용 에서의 발달 양상을 생애 전반에 걸쳐 살펴본 연구들은 찾아보기 힘들며, 연령에 따른 변화를 살펴보는 경우도 대부분 특정 시기에 중점을 두어 진행된 연구가 대부분이다. 또한 어휘를 연구하는 방 법이나 측정치도 일관되지 않아 아동기에서 노년기까지의 어휘 사 용 발달을 하나의 관점으로 이해하기 힘들다. 본 연구는 이러한 배 경 하에, 아동기에서 노년기까지의 어휘 사용 발달을 연속된 관점 에서 살펴보기 위해 동일 절차를 통해 수집된 50 개 발화에서의 전 
체 어휘 수(TNW)와 다른 낱말 수(NDW), 어휘다양도(TTR)를 중 심으로 살펴보고자 하였다. 또한 여러 측정치들 중에서 연령 집단 을 가장 판별해 준 측정치가 무엇인지를 확인하고자 하였다.

\section{연구방법}

\section{연구대상}

본 연구는 생애 발달을 초기 아동기, 후기 아동기, 청소년기, 초기 성인기, 후기 성인기, 노년기의 6시기로 구분하고 각각의 시기별로 20 명씩, 총 120 명을 연구대상으로 포함하였다. 생애 시기에 대한 구 분은 발달심리학자인 Havighurst (1973)의 발달시기 분류에 근거 하였으며, 초기 아동기는 3세부터 6세로 유아기에 해당하며, 후기 아동기는 7 세부터 12 세의 학령기 아동, 청소년기는 13 세부터 18 세, 초기 성인기는 19세에서 35 세, 후기 성인기는 36세에서 60세, 그리 고 노년기는 61세 이상으로 하였다.

전형적 발달에 해당하는 사람만을 포함하기 위하여, 초기 아동 기부터 청소년기까지는 주 양육자 또는 교사에 의해 신체, 운동, 감 각, 정서 등에 특별한 문제가 없으며, 수용·표현어휘력검사(REVT; Kim, Hong, Kim, Jang, \& Lee, 2009)를 실시하여 언어능력이 정상 범위에 속하는 경우 연구참가자에 포함하였다. 청소년 중 REVT 규준이 없는 연령은 한국판 웩슬러 성인지능검사 4판(K-WAIS-4; Hwang, Kim, Park, Choi, \& Hong, 2012)의 소검사 중 ‘어휘'와 ‘이 해'에서 환산점수 평균인 10점으로부터 -1 표준편차 이상에 해당 하는 경우를 포함하였다. 초기 성인기에서 노년기는 건강선별설문 지(Christensen, Multhaup, Nordstrom, \& Voss, 1991)와 한국판 간 이정신상태 검사(Korean-Mini Mental State Examination, K-MMSE; Kang, 2006)를 실시하여 언어능력에 영향을 미칠 수 있는 정신적, 신경학적 질환의 병력이 없고 정상범위의 인지기능을 갖고 있는 것 으로 판단된 경우 연구참가자로 포함하였다. 연구에 참여한 연구 대상 정보는 Table 1에 제시하였다.

\section{자료수집 도구 및 절차}

어휘는 발화를 수집하는 자료나 절차에 의해 영향을 받을 수 있 으므로 모든 참가자들에게 동일한 절차를 통해 대화자료를 수집하 고자 한림 대화·화용 평가 프로토콜(Lee \& Choi, in press) 중 대화
절차를 사용하였다. 이 절차는 각 대상자에게 3 가지의 대화 주제를 각각 4 가지의 사진으로 제공하고 대화를 유도하는 것으로, 어휘는 대화 주제에 의해 영향을 받을 수 있기 때문에 대화 주제를 통제하 였다. 아동 및 청소년에게는 '가정생활, 학교(유치원)생활, 기타/친 구'를, 성인 및 노인에게는 '여가생활, 가정생활, 기타/친구'를 대화 주제로 제공하였다. 모든 연령에 '가정생활’과 ‘친구’를 공통된 주제 로 제공하였으며, 연령에 따른 차이를 반영하여 아동 및 청소년에 게는 '학교(유치원)생활'을, 성인 및 노인에게는 '여가생활'을 추가 하였다. 각각의 대화 주제별로 3 가지의 소주제 질문을 사전에 준비 하였으며, 소주제는 '가정생활'에 주말, 명절, 생일, '학교생활'에는 점심/쉬는시간, 방과후, 현장학습, '기타/친구'에는 놀이, 좋아하는 것 TV프로그램, '여가생활'에는 휴식시간, 취미활동, 모임활동이었 다. 대화를 유도하기 위해 제공한 사진은 가로 $110 \mathrm{~mm}$, 세로 $85 \mathrm{~mm}$ 였으며, 노인의 경우에는 사진의 크기를 확대하여 가로 $200 \mathrm{~mm}$, 세 로 $160 \mathrm{~mm}$ 크기로 준비하였다.

대화수집 절차는 다음과 같았다. 먼저 참가자에게 각각의 주제 별로 준비된 사진을 2 개의 봉투에 담아 제시한 후 하나를 선택하게 하였다. 참가자가 하나의 봉투를 선택하면 그 속에 담겨 있는 사진 들을 꺼내 참가자 앞에 펼쳐주어 살펴보게 한 후, 대화를 개시할 수 있는 기회를 제공하였다. 대상자가 자발적으로 개시하는 경우에는 자연스럽게 대화를 이어나갔으나, 참가자가 먼저 대화를 개시하지 않는 경우에는 3 초를 기다렸다가 "가정생활은 어때(어떠세요)?" 또는 “학교생활은 어때(어떠세요)?"라고 해당 주제를 언급해 주었 다. 언급해주어도 반응이 없는 경우, 준비된 소주제 질문을 하나씩 제공하였다. 그리고 준비한 소주제로 대화가 완료되면 대화를 종결 하였다.

대화 자료는 대화상대자의 반응에 따라 달라질 수 있으므로 대 화상대자로 참여하는 검사자의 영향을 최소화하도록 반응절차를 다음과 같이 구조화하였다. (1) 참가자가 자신의 대화차례에서 발 화를 할 때, 대화차례를 받지 않는 선에서 '응, 그래, 그렇구나' 등의 중립적인 반응으로 호응해준다. (2) 참가자가 3 초 동안 아무 말을 하 지 않거나, 끝맺는 말 또는 억양을 사용하는 경우 대화차례가 끝났 다고 간주하고, 검사자는 대상자의 발화를 반복해서 대화차례를 이어준다. (3) 검사자의 대화차례 이후에 참가자가 발화를 이어나가 지 않는 경우 3 초를 기다렸다가 “그리고?", "또?”와 같이 촉진해준

Table 1. Participants' information

\begin{tabular}{lccccccc}
\hline & $E C(N=20)$ & $L C(N=20)$ & $\operatorname{Adc}(N=20)$ & $Y A(N=20)$ & $L A(N=20)$ & $E d(N=20)$ & Total $(N=120)$ \\
\hline Age $(y r)$ & $5.55(.51)$ & $10.10(1.58)$ & $16.35(1.87)$ & $28.40(5.15)$ & $53.30(5.03)$ & $67.40(5.23)$ & $30.18(23.21)$ \\
\hline
\end{tabular}

Values are presents as mean (SD).

$E C=$ early childhood (preschooler); $\mathrm{LC}=$ late childhood (schoolaged child); $\mathrm{Adc}=$ adolescent; $Y \mathrm{~A}=$ young adult; $\mathrm{OA}=$ older adult; $\mathrm{Ed}=$ elderly. 
다. (4) 참가자가 끝맺는 말, 할 말이 없다는 행동(시선, 미소, 무반응 등)을 보이면, 언급하지 않았던 소주제의 질문을 하거나 다음 화제 를 선택하게 한다.

자료수집에 참여하는 검사자는 언어병리학전공 석사과정 5명으 로, 자료수집 전 언어병리학교수 1 인과 박사과정 1 인이 언어수집 절 차에 대해 다음과 같은 절차로 훈련을 진행하였다. 박사과정 1 인이 검사자 5명(언어병리학전공 석사)에게 수집 절차에 대해 설명해 준 후, 일주일 이내로 1-2명을 대상으로 예비 연구를 실시하도록 하였 다. 예비 연구를 통해 수집된 자료는 박사과정 1 인이 녹음된 자료와 전사된 자료를 다시 재검토한 후 정해진 절차를 충실히 따랐다고 판단된 후 실제 자료수집을 진행하도록 하였다. 자료수집 절차에 대해 완벽하게 숙지된 검사자는 대상자 모집을 통해 개별 연락이 닿은 어머니 또는 관련 기관과 검사 일정을 조율하였다. 모든 대상 자 또는 대상자의 보호자에게 연구목적과 절차 및 검사 내용 등이 포함된 연구참여동의서를 받은 후 자료수집을 실시하였다. 모든 대 화 내용은 추후 분석을 위하여 녹음전용 MP3 (ICD-TX800)를 이 용하여 녹음하였다.

\section{자료 전사 및 분석}

녹음된 자료는 언어자료를 수집한 검사자가 1 주일 이내에 언어 전사를 완료하였다. 전사된 자료 중 50 개 발화만을 분석에 포함시 켰으며, 포함한 50 개 발화는 대화 주제에 따른 언어 사용 영향을 최 소화 하기 위하여 세 가지 대화 주제의 비율을 각각 $40 \%, 40 \%, 20 \%$ 의 비율로 동일하게 하였다. 발화 선택 시, 각 주제의 대화 시작 부 분부터 연속된 발화를 선택하여 주제별 발화 비율을 조정하였다. 각 주제별 발화수가 전사된 50개 발화는 컴퓨터 어휘 분석기를 사 용하여 표준국어문법에서 제시한 9품사로 분석하였고, 2차적으로 연구자들이 분석된 파일을 검토하여 최종 분석하였다.

품사는 학교 문법을 기준으로 하되, 이 중 자립하여 의미를 표현 하는 단어만을 포함하여 최종적으로 조사를 제외한 8품사인 명사 (자립명사, 의존명사, 고유명사), 대명사, 동사(본 동사, 보조 동사), 형용사(본 형용사, 보조 형용사), 부사, 감탄사, 관형사, 수사를 분석 에 포함하였다. 품사 구분이 어렵거나 복합어인 경우 네이버 국어 사전(http://krdic.naver.com/)의 표제어 상태에 따라 품사를 결정 하였다. 즉 사전에 실려 있는 경우 하나의 단어로, 그렇지 않은 경우 에는 여러 단어가 결합하여 형성된 것으로 간주하였다(Lee \& Kim, 2004).

분석한 단어는 전체 낱말 수(TNW), 다른 낱말 수(NDW), 어휘 다양도(TTR)를 산출하였다. TNW는 50 개 발화의 언어 샘플에서 나타난 전체 낱말 수의 합으로, NDW는 50 개 발화의 언어샘플에
서 나타난 다른 낱말 수의 합으로 산출하였으며, TTR은 다른 낱말 수를 전체 낱말 수로 나누어 계산하였다. TNW, NDW, TTR은 전 체와 품사별로 나누어 산출하였다.

\section{신뢰도}

자료전사 및 분석에 대한 신뢰도는, 검사자와 평가자 간의 일치 도로 측정하였다. 신뢰도 평가자는 언어병리학을 전공하는 박사과 정생 1 인으로 선정하였다. 평가자는 연구 내용을 잘 알고 있으며, 전사 및 분석 기준을 신뢰도 산출 이전에 충분히 숙지하도록 하였 다. 검사자와 평가자는 전사 및 분석한 내용에서 불일치한 항목에 대해 다시 함께 살펴보고 합의하여 최대한 일관되도록 조정하였다. 전사 및 분석 연습이 끝난 후, 전체 자료의 $10 \%$ 인 12 명(집단별 2 명) 을 무작위로 추출하여 평가자가 독립적으로 전사하고 분석하였다. 전사 신뢰도의 경우, 녹음된 자료 중 분석에 포함된 50 발화에 해당 하는 부분 중 일치하지 않은 부분을 일치한 부분에서 뺀 발화를 전체 발화로 나누어 측정하였다. 분석 신뢰도의 경우, 품사별 전체 낱말 수에서 일치하지 않은 부분을 일치한 부분에서 뺀 후 전체 낱 말 수로 나누어 측정하였다. 일치도 측정결과 전사는 $96 \%$, 분석 일 치도는 명사 $99.22 \%$, 대명사 $94.41 \%$, 수사 $90.20 \%$, 동사 $100 \%$, 형용 사 $100 \%$, 감탄사 $92.31 \%$ 로 측정되었다.

\section{연구결과}

\section{연령별 어휘 사용 양상의 차이}

전체 발화에서의 TNW, NDW, TTR

$\mathrm{TNW}$ 와 NDW 모두 초기 아동기에서 청소년기까지는 증가하였 으며, 초기 성인기에 감소한 후 노년기까지는 비슷하게 유지되었으 며, TTR은 청소년기까지는 서서히 감소하다가 초기 성인기에 약간 증가하여 노년기까지 비슷하게 유지되었다. ANOVA를 통해 연령 집단에 따른 차이를 검정한 결과, $\mathrm{TNW}\left(F_{(5,119)}=5.636, p<.001\right)$, $\operatorname{NDW}\left(F_{(5,119)}=5.295, p<.001\right), \operatorname{TTR}\left(F_{(5,119)}=8.510, p<.001\right)$ 모두 유의한 차이를 보였다(Table 2, Figure 1). TNW와 NDW 모두 초기 아동기 집단이 청소년, 성인, 중년, 노년 집단보다 유의하게 적은 어 휘를 사용하였으며, 후기 아동 집단이 청소년 집단보다 유의하게 적은 어휘를 사용한 것으로 나타났다. TTR은 초기 아동기 집단이 다른 연령 집단에 비해 유의하게 높은 것으로 나타났다(Table 3).

\section{품사별 TNW, NDW, TTR}

품사별 TNW는 모든 연령에서 명사가 차지하는 비율이 $40 \%$ 이 상으로 가장 높았으며, 그 다음으로는 동사가 $27 \%-29 \%$ 로 그 다음 
Table 2. Results of ANOVA in total TNW, NDW, TTR according to age group

\begin{tabular}{lccccccc}
\hline & EC & LC & Adc & YA & OA & Ed & $F$ \\
\hline TNW & $263.20(77.37)$ & $340.05(167.08)$ & $540.80(149.32)$ & $418.75(71.39)$ & $485.05(144.82)$ & $412.37(329.57)$ & $6.330^{* * *}$ \\
NDW & $133.50(28.49)$ & $157.60(56.16)$ & $220.75(55.82)$ & $181.45(31.96)$ & $206.50(52.36)$ & $181.37(111.39)$ & $5.295^{* * *}$ \\
TTR & $.52(.07)$ & $.49(.07)$ & $.41(.04)$ & $.44(.07)$ & $.44(.05)$ & $.46(.06)$ & $8.510^{* * *}$
\end{tabular}

Values are presents as mean (SD).

$\mathrm{EC}=$ early childhood (preschooler); $\mathrm{LC}=$ late childhood (schoolaged child); $\mathrm{Adc}=$ adolescent; $Y \mathrm{~A}=$ young adult; $\mathrm{OA}=$ older adult; $\mathrm{Ed}=$ elderly; TNW=total number of words; $\mathrm{NDW}=$ number of different words; $T \mathrm{TR}=$ type-token ratio.
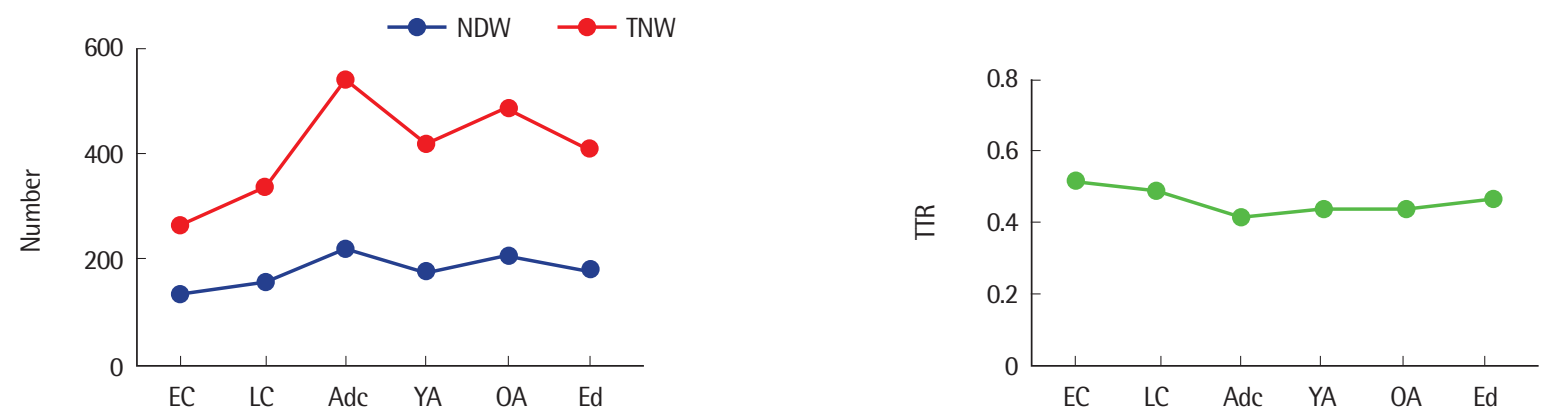

Figure 1. The total TNW and NDW according to age group.

TNW = total number of word; NDW= number of different word; $T R R=$ type-token ratio; $E C=$ early childhood; $L C=$ late childhood; $A d c=$ adolescent; $Y A=y o u n g$ adult; $\mathrm{OA}=$ older adult; $\mathrm{Ed}=$ elderly.

Table 3. Results of post-hoc analysis

\begin{tabular}{|c|c|c|c|c|c|c|c|c|c|c|c|c|c|c|c|}
\hline & \multicolumn{3}{|c|}{ LC } & \multicolumn{3}{|c|}{ Adc } & \multicolumn{3}{|c|}{ YA } & \multicolumn{3}{|c|}{ LA } & \multicolumn{3}{|c|}{$\mathrm{Ed}$} \\
\hline & TTR & TNW & NDW & $T \mathrm{TR}$ & TNW & NDW & TTR & TNW & NDW & TTR & TNW & NDW & TTR & TNW & NDW \\
\hline EC & & & & $\begin{array}{l}\text { T, N, PN, V, } \\
\text { Adj, Ad, D }\end{array}$ & $\begin{array}{c}\text { T, N,V, Adj, } \\
\text { Ad, D, E }\end{array}$ & $\begin{array}{c}\text { T, N, V } \\
\text { Adj, Ad, D D }\end{array}$ & $\begin{array}{c}\text { T, N, V, } \\
\text { Adj, D, E }\end{array}$ & Adj, Ad & $\mathrm{Ad}$ & $\begin{array}{c}\text { T, N, Adj, } \\
\text { Ad, D }\end{array}$ & $\begin{array}{c}\text { T, N, V } \\
\text { Adj, Ad, E }\end{array}$ & $\begin{array}{c}\text { T, N, Adj, } \\
\text { Ad, E }\end{array}$ & $\begin{array}{l}\text { T, N, V, } \\
\text { Adj, D }\end{array}$ & Adj, Ad & $\mathrm{Ad}$ \\
\hline $\mathrm{LC}$ & & & & T, PN, V & $\begin{array}{c}\text { T, N, Adj, } \\
\text { Ad, D, E }\end{array}$ & $\begin{array}{l}\text { T, N, Adj, } \\
\text { Ad, D, E }\end{array}$ & V, Adj & Adj & $\mathrm{Ad}$ & $\begin{array}{l}\text { PN, V, } \\
\text { Adj }\end{array}$ & Adj, Ad, E & $\underset{E}{\operatorname{Adj}, A d,}$ & PN, V & & \\
\hline Adc & & & & & & & $\mathrm{Ad}$ & $\mathrm{Ad}, \mathrm{E}$ & $\mathrm{D}, \mathrm{E}$ & $\mathrm{Ad}$ & D & & $\mathrm{Ad}$ & $\mathrm{Ad}, \mathrm{E}$ & $D, E$ \\
\hline YA & & & & & & & & & & $E$ & $E$ & & & & \\
\hline LA & & & & & & & & & & & & & & E & E \\
\hline
\end{tabular}

$\mathrm{EC}=$ early childhood (preschooler); $\mathrm{LC}=$ late childhood (schoolaged child); $\mathrm{Adc}=$ adolescent; $Y \mathrm{~A}=$ young adult; $\mathrm{OA}=$ older adult; $E d=$ elderly; $T=$ total; $N=$ noun; $P N=$ pronoun; $\mathrm{V}=$ verb; $\mathrm{Adj}=$ adjective; $\mathrm{Ad}=$ adverb; $\mathrm{D}=$ determinant; $\mathrm{E}=$ exclamation.

으로는 부사가 $10 \%-13 \%$, 형용사가 5\%-10\% 정도를 차지하였다. 그 외 다른 품사들은 $5 \%$ 미만의 낮은 사용 비율을 보였다.

연령에 따라서는 수사를 제외한 모든 품사에서 청소년기까지 $\mathrm{TNW}$ 가 급격히 증가하는 양상을 보였으며, 명사, 대명사, 부사는 초기 성인기에 약간 감소한 후 노년기까지 비슷하게 유지되었고 동 사와 형용사는 초기 성인기부터 노년기까지 계속 비슷한 수준을 유지하였다. 수사는 초기 성인기까지 거의 변화가 없다가 후기 성인 기와 노년기에 증가하였으며, 감탄사는 청소년과 나이든 성인 집단 에서만 관찰되었다(Table 4, Figure 2).

$\mathrm{ANOVA}$ 를 통해 연령 집단에 따른 차이를 검정한 결과, 대명사 와 수사를 제외한 명사 $\left(F_{(5,119)}=3.934, p<.01\right)$, 동사 $\left(F_{(5,119)}=4.257\right.$, $p<.01)$, 형용사 $\left(F_{(5,119)}=10.676, p<.001\right)$, 부사 $\left(F_{(5,119)}=17.915\right.$, $p<.001)$, 관형사 $\left(F_{(5,119)}=3.949, p<.01\right)$, 감탄사 $\left(F_{(5,119)}=11.342\right.$, $p<.001)$ 의 전체 어휘 수에서 유의한 차이를 보였다. 사후분석 결 과, 어린 유아 집단과 아동 집단은 청소년기 이후의 연령 집단에서 거의 대부분의 품사에서 유의한 차이를 보였고, 청소년기 이후의 집단에서는 부사, 형용사, 감탄사, 관형사에서 유의한 차이를 보이 는 것으로 나타났다(Table 3 ).

품사별 NDW 역시 모든 연령에서 명사가 차지하는 비율이 $45 \%$ 이상으로 가장 높았으며, 그 다음으로는 동사가 $20 \%-25 \%$ 로 그 다 음으로는 부사가 $10 \%-14 \%$, 형용사가 6\%-10\% 정도를 차지하였으 며, 그 외 다른 품사들은 $5 \%$ 미만의 낮은 사용 비율을 보여 대체로 
Table 4. Results of ANOVA in TNW per word class according to age group

\begin{tabular}{|c|c|c|c|c|c|c|c|c|}
\hline & & EC & LC & Adc & YA & $\mathrm{OA}$ & $\mathrm{Ed}$ & $F$ \\
\hline \multirow[t]{2}{*}{ Noun } & TNW & $121.55(37.06)$ & 143.45 (68.62) & $216.45(59.54)$ & $182.30(32.63)$ & 199.20 (58.85) & 173.53 (156.54) & $3.934^{* *}$ \\
\hline & $\%$ & $46.69(7.43)$ & $43.16(5.31)$ & $40.24(3.67)$ & $43.55(2.97)$ & $41.21(4.03)$ & 41.21 (4.39) & \\
\hline \multirow[t]{2}{*}{ Verb } & TNW & 78.75 (27.37) & $103.65(61.67)$ & 146.90 (39.33) & $121.05(23.49)$ & 133.25 (38.58) & 116.89 (89.52) & $4.257^{* *}$ \\
\hline & $\%$ & $29.63(4.31)$ & 29.65 (3.92) & $27.28(2.69)$ & $28.95(3.12)$ & $27.75(3.17)$ & $27.24(7.13)$ & \\
\hline \multirow[t]{2}{*}{ Adverb } & TNW & $26.30(11.70)$ & 40.60 (22.91) & $85.25(28.78)$ & $51.85(11.05)$ & $63.45(23.63)$ & 46.32 (24.33) & $17.915^{* * *}$ \\
\hline & $\%$ & 9.87 (9.69) & $11.96(3.42)$ & $15.70(2.49)$ & $12.75(2.16)$ & $12.99(2.82)$ & $13.06(4.95)$ & \\
\hline \multirow[t]{2}{*}{ Adjective } & TNW & $14.30(8.76)$ & 18.60 (8.94) & $39.35(17.16)$ & $37.90(10.55)$ & $40.85(16.72)$ & $32.05(25.12)$ & $10.676^{* * *}$ \\
\hline & $\%$ & $5.34(2.78)$ & $5.59(1.59)$ & 7.09 (2.03) & 9.09 (2.18) & $8.51(2.51)$ & $9.84(8.96)$ & \\
\hline \multirow[t]{2}{*}{ Pronoun } & TNW & $13.40(8.44)$ & 20.70 (33.96) & $27.20(10.50)$ & $15.25(8.36)$ & $21.95(10.57)$ & $25.63(17.58)$ & 1.970 \\
\hline & $\%$ & 4.91 (2.39) & $5.80(7.23)$ & $4.98(1.50)$ & $3.58(1.62)$ & 4.51 (1.69) & $6.53(2.17)$ & \\
\hline \multirow[t]{2}{*}{ Determinant } & TNW & $7.70(5.40)$ & $11.70(8.41)$ & $22.00(12.12)$ & $13.05(6.44)$ & $16.75(10.93)$ & $16.89(18.70)$ & $3.949^{* *}$ \\
\hline & $\%$ & 3.02 (2.08) & $3.42(1.63)$ & $3.98(1.51)$ & $3.05(1.25)$ & $3.26(1.74)$ & $4.00(1.50)$ & \\
\hline \multirow[t]{2}{*}{ Exclamation } & TNW & $1.00(.56)$ & $.55(.51)$ & $2.70(2.51)$ & $.75(1.16)$ & $3.60(2.64)$ & $.89(1.15)$ & $11.342^{* * *}$ \\
\hline & $\%$ & $.43(.33)$ & $.17(.18)$ & $.52(.54)$ & $.17(.27)$ & $.74(.43)$ & $.78(2.28)$ & \\
\hline \multirow[t]{2}{*}{ Numerical } & TNW & $.20(.52)$ & $.80(1.73)$ & $.95(1.57)$ & $.45(.82)$ & $3.00(4.09)$ & 2.68 (7.98) & 1.997 \\
\hline & $\%$ & $.06(.16)$ & $.22(.49)$ & $.16(.25)$ & $.10(.19)$ & $.58(.78)$ & $2.22(8.47)$ & \\
\hline
\end{tabular}

Values are presents as mean (SD).

TNW = total number of word; $\mathrm{EC}=$ early childhood (preschooler); $\mathrm{LC}=$ late childhood (schoolaged child); $\mathrm{Adc}=$ adolescent; $Y \mathrm{~A}=$ young adult; $\mathrm{OA}=$ older adult; $\mathrm{Ed}=$ elderly. ${ }^{* *} p<.01,{ }^{* * *} p<.001$.

Table 5. Results of ANOVA in NDW per word class according to age group

\begin{tabular}{|c|c|c|c|c|c|c|c|c|}
\hline & & EC & LC & Adc & YA & $\mathrm{OA}$ & $\mathrm{Ed}$ & $F$ \\
\hline \multirow[t]{2}{*}{ Noun } & NDW & $66.75(14.48)$ & 71.95 (24.79) & 103.65 (28.49) & $87.05(14.31)$ & $100.60(25.02)$ & 90.37 (65.98) & $4.002^{* *}$ \\
\hline & $\%$ & $50.43(6.93)$ & $46.42(6.78)$ & $47.06(4.55)$ & $48.26(4.62)$ & $48.86(4.48)$ & $48.94(4.25)$ & \\
\hline \multirow[t]{2}{*}{ Verb } & NDW & $33.55(9.21)$ & 40.60 (18.44) & $50.85(16.19)$ & 39.65 (5.67) & 45.35 (13.33) & 38.68 (19.58) & $3.342^{* *}$ \\
\hline & $\%$ & 25.00 (3.94) & 25.21 (3.22) & $22.70(3.47)$ & 22.11 (2.59) & $22.00(2.84)$ & 20.66 (5.54) & \\
\hline \multirow[t]{2}{*}{ Adverb } & NDW & $12.95(5.05)$ & $16.40(7.12)$ & $28.95(6.03)$ & $24.70(4.79)$ & 26.35 (9.06) & $22.74(10.46)$ & $13.936^{* * *}$ \\
\hline & $\%$ & $9.53(3.03)$ & $10.55(3.47)$ & $13.32(1.73)$ & $13.69(2.08)$ & $12.69(2.64)$ & $13.36(2.04)$ & \\
\hline \multirow[t]{2}{*}{ Adjective } & NDW & $8.85(4.06)$ & $10.45(4.22)$ & $16.90(6.35)$ & $13.45(3.98)$ & $17.20(6.11)$ & $13.74(9.07)$ & $6.488^{* * *}$ \\
\hline & $\%$ & $6.51(2.62)$ & $6.86(2.75)$ & $7.59(2.05)$ & $7.40(1.75)$ & $8.31(1.80)$ & $9.98(11.11)$ & \\
\hline \multirow[t]{2}{*}{ Pronoun } & NDW & $5.20(1.98)$ & $10.05(17.04)$ & $8.05(2.94)$ & $5.70(2.20)$ & $6.40(2.43)$ & $7.00(2.86)$ & 1.159 \\
\hline & $\%$ & $3.93(1.37)$ & $5.71(6.76)$ & $3.62(1.02)$ & $3.18(1.17)$ & $3.13(1.09)$ & $4.17(1.21)$ & \\
\hline \multirow[t]{2}{*}{ Determinant } & NDW & $4.50(2.85)$ & $6.90(3.55)$ & 9.95 (3.85) & $6.20(3.05)$ & $6.70(3.43)$ & $6.68(3.83)$ & $5.250^{* * *}$ \\
\hline & $\%$ & $3.30(1.80)$ & $4.43(1.75)$ & $4.63(1.89)$ & $3.33(1.29)$ & $3.15(1.37)$ & $3.96(1.60)$ & \\
\hline \multirow[t]{2}{*}{ Exclamation } & NDW & $1.00(.56)$ & $.55(.51)$ & $1.65(1.18)$ & $.45(.60)$ & $1.90(.96)$ & $.68(.74)$ & $11.380^{* * *}$ \\
\hline & $\%$ & $.81(.56)$ & $.35(.36)$ & $.73(.53)$ & $.26(.40)$ & $.93(.50)$ & $.89(2.14)$ & \\
\hline \multirow[t]{2}{*}{ Numerical } & NDW & $.20(.52)$ & $.70(1.65)$ & $.75(1.20)$ & $.40(.68)$ & $2.00(2.49)$ & 1.58 (3.74) & 2.378 \\
\hline & $\%$ & $.13(.33)$ & .44 (1.03) & $.31(.49)$ & $.19(.32)$ & $.89(1.07)$ & $1.88(6.01)$ & \\
\hline
\end{tabular}

Values are presents as mean (SD).

$\mathrm{NDW}=$ number of different word; $\mathrm{EC}=$ early childhood (preschooler); $\mathrm{LC}=$ late childhood (schoolaged child); $\mathrm{Adc}=$ adolescent; $Y \mathrm{~A}=$ young adult; $\mathrm{OA}=$ older adult; $\mathrm{Ed}=$ elderly. ${ }^{* *} p<.01,{ }^{* * *} p<.001$.

TNW와 유사하였다.

연령에 따라서는 명사, 동사, 형용사, 부사는 청소년기까지 약간 증가하였으나 그 이후로는 노년기까지 큰 변화가 없었다. 반면, 대명 사는 후기 아동기에 증가하였다가 청소년기에 약간 감소한 후 노년 기까지 비슷한 수준을 보였으며, 관형사는 청소년기까지 증가하였
다가 초기 성인기에 감소한 후 노년기까지 비슷하게 유지되었다. 수 사는 초기 성인기까지 거의 변화가 없다가 후기 성인기와 노년기에 증가하였으며, 감탄사는 청소년과 후기 성인 집단에서만 관찰되었 다(Table 5, Figure 3). ANOVA를 통해 연령 집단에 따른 차이를 검 정한 결과, TNW와 마찬가지로 대명사와 수사를 제외한 명사 

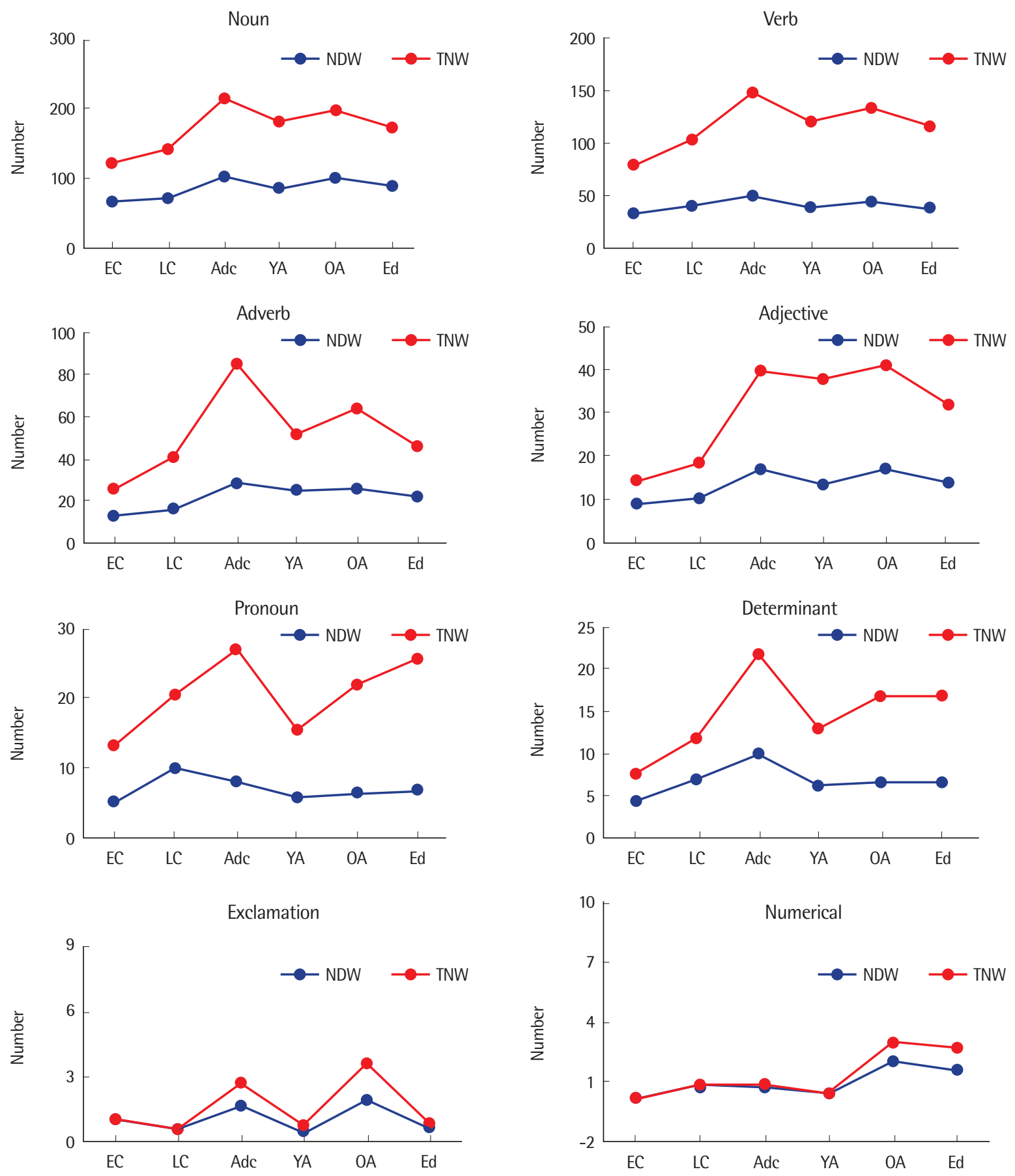

Figure 2. The TNW and NDW per word class according to age group.

TNW = total number of word; NDW= number of different word; $E C=$ early childhood (preschooler); $L C=$ late childhood (schoolaged child); $A d c=$ adolescent; $Y A=$ young adult; $O A=$ older adult; $E d=$ elderly.

$\left(F_{(5,119)}=4.002, p<.01\right)$, 동사 $\left(F_{(5,119)}=3.342, p<.01\right)$, 형용사 $\left(F_{(5,119)}=6.488, p<.001\right)$, 부사 $\left(F_{(5,119)}=13.936, p<.001\right)$, 관형사 $\left(F_{(5,119)}=5.250, p<.001\right)$, 감탄사 $\left(F_{(5,119)}=11.380, p<.001\right)$ 에서 유의 한 차이를 보였다. 사후분석 결과 초기 아동기와 후기 아동기 집단
은 청소년기 이후의 연령 집단에서 거의 대부분의 품사에서 유의 한 차이를 보였고, 청소년기 이후의 집단에서는 부사, 형용사, 감탄 사, 관형사에서 유의한 차이를 보이는 것으로 나타났다(Table 3).

품사별 TTR은 .15-.85 범위를 보였다. 초기 아동기 집단의 수사 

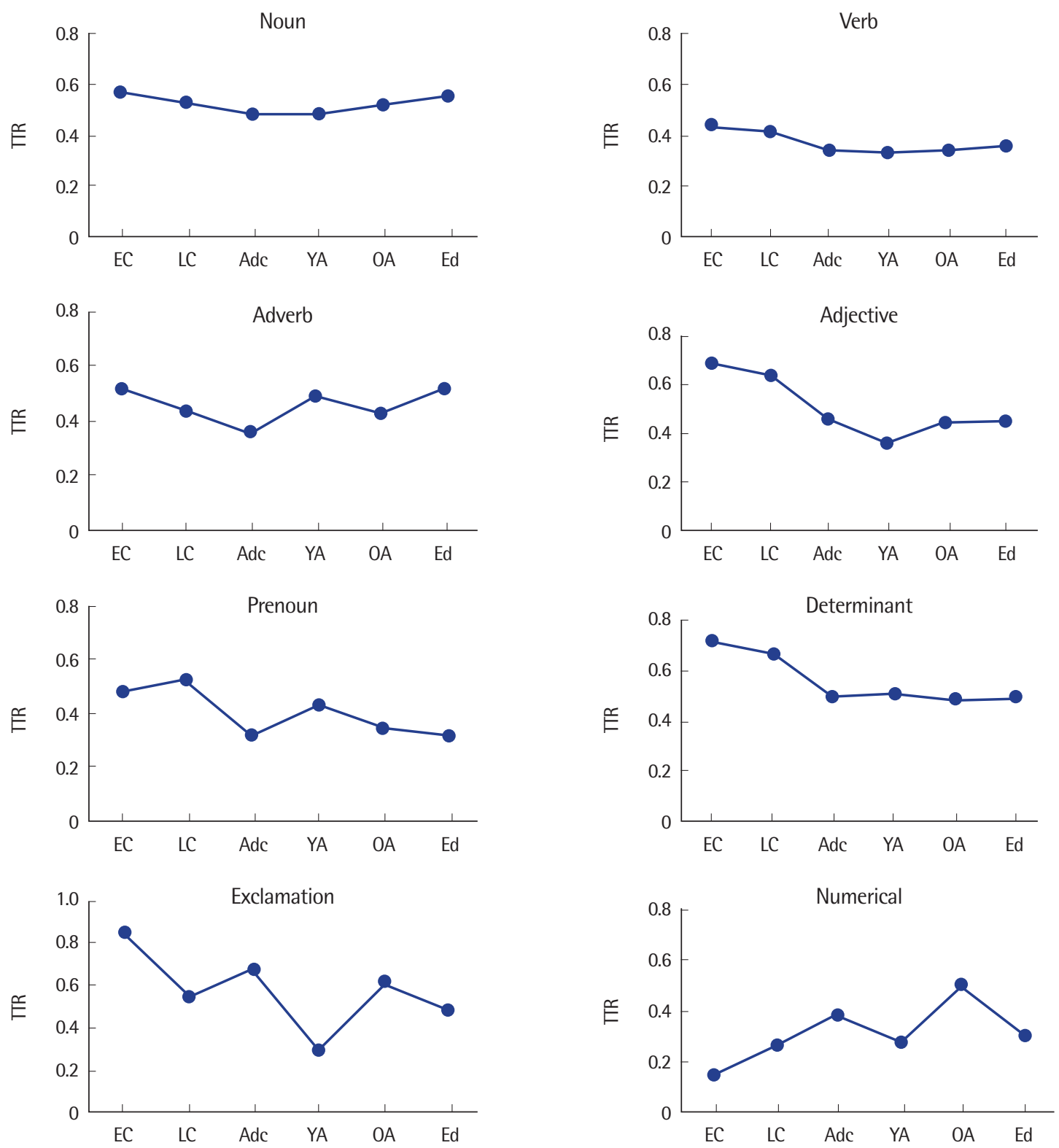

Figure 3. The TTR per word class according to age group.

TTR= type-token ratio; $\mathrm{EC}=$ early childhood (preschooler); $\mathrm{LC}=$ late childhood (schoolaged child); $\mathrm{Adc}=$ adolescent; $\mathrm{YA}=$ young adult; $\mathrm{OA}=$ older adult; $\mathrm{Ed}=$ elderly.

가 .15 로 가장 낮았으며, 감탄사가 .85로 가장 높았다. 대체로 초기 아동기와 후기 아동기 집단에서는 대부분이 .5 이상 높은 TTR을 보였다. 반면 청소년과 초기 성인기 집단은 절반의 품사에서 .4이 하를 보여 대체로 낮은 TTR을 보였다. 명사에서는 대체로 모든 연 령 집단이 높은 TTR을 보였고, 동사는 청소년부터 노년기까지, 수 사는 후기 성인기 집단을 제외한 모든 연령 집단에서 낮은 TTR을 보였다(Table 6, Figure 3).

$\mathrm{ANOVA}$ 를 통해 연령 집단에 따른 차이를 검정한 결과, 수사를
제외한 명사 $\left(F_{(5,119)}=4.107, p<.01\right)$, 대명사 $\left(F_{(5,119)}=6.430, p<.001\right)$, 동사 $\left(F_{(5,119)}=8.693, p<.001\right)$, 형용사 $\left(F_{(5,119)}=7.377, p<.001\right)$, 부사 $\left(F_{(5,119)}=8.359, p<.001\right)$, 관형사 $\left(F_{(5,119)}=5.103, p<.001\right)$, 감탄사 $\left(F_{(5,119)}=3.768, p<.01\right)$ 에서 유의한 차이를 보였다. 사후분석 결과 초기 아동기와 후기 아동기 집단은 청소년기 이후의 연령 집단과 대부분의 품사에서 유의한 차이를 보였고, 청소년기 이후의 집단 에서는 부사와 감탄사에서 유의한 차이를 보이는 것으로 나타났다 (Table 3). 연령 집단에 따른 TNW, NDW, TTR의 사후분석 결과는 
Table 6. Results of ANOVA in TTR per word class according to age group

\begin{tabular}{|c|c|c|c|c|c|c|c|}
\hline & EC & LC & Adc & YA & $\mathrm{OA}$ & $\mathrm{Ed}$ & $F$ \\
\hline Noun & $.56(.08)$ & $.52(.08)$ & $.48(.04)$ & $.48(.06)$ & $.51(.06)$ & $.55(.06)$ & $4.107^{* *}$ \\
\hline Verb & $.44(.07)$ & $.41(.09)$ & $.34(.06)$ & $.33(.06)$ & $.34(.04)$ & $.35(.06)$ & $8.693^{* * *}$ \\
\hline Adverb & $.52(.11)$ & $.43(.11)$ & $.35(.07)$ & $.48(.08)$ & $.42(.07)$ & $.51(.09)$ & $8.359^{* * *}$ \\
\hline Adjective & $.68(.16)$ & $.63(.42)$ & $.46(.14)$ & $.36(.09)$ & $.44(.09)$ & $.44(.08)$ & $7.377^{* * *}$ \\
\hline Pronoun & $.48(.19)$ & $.52(.18)$ & $.31(.08)$ & $.42(.17)$ & $.34(.18)$ & $.31(.10)$ & $6.430^{* * *}$ \\
\hline Determinant & $.72(.26)$ & $.66(.16)$ & $.49(.15)$ & $.51(.17)$ & $.49(.23)$ & $.49(.19)$ & $5.103^{* * *}$ \\
\hline Exclamation & $.85(.36)$ & $.55(.51)$ & $.67(.35)$ & $.29(.41)$ & $.61(.31)$ & $.48(.56)$ & $3.768^{* *}$ \\
\hline Numerical & $.15(.36)$ & $.26(.44)$ & $.38(.45)$ & $.28(.44)$ & $.50(.43)$ & $.30(.43)$ & 1.560 \\
\hline
\end{tabular}

Values are presents as mean (SD).

$\Pi \mathrm{R}=$ type-token ratio; $E \mathrm{E}=$ = early childhood (preschooler); $\mathrm{LC}=$ late childhood (schoolaged child); $\mathrm{Adc}=$ adolescent; $\mathrm{YA}=$ young adult; $\mathrm{OA}=$ older adult; $\mathrm{Ed}=$ elderly. ${ }^{* *} p<.01,{ }^{* * *} p<.001$.

Table 3에 요약하여 제시하였다.

\section{품사별 사용을 통한 연령 집단 판별분석}

$\mathrm{TNW}$ 와 NDW 중 연령 집단 특성을 가장 잘 판별할 수 있는 판 별 함수를 도출하고, 독립변수의 상대적 기여도를 파악하기 위해 단계선택방식의 판별분석(stepwise estimation-discriminate analysis)을 실시하였다. 연령 집단 간 유의한 차이를 보인 전체 TNW와 $\mathrm{NDW}$, 명사, 동사, 부사, 형용사, 관형사, 수사, 감탄사의 TNW, NDW 총 14 개 종속측정치를 입력하여 분석한 결과, 종속측정치들이 연 령 집단을 의미 있게 판별해주는 요인으로 확인되었으며(eigenval$\mathrm{ue}=1.092$, 정준상관계수 $=.722$, Wilks의 $\lambda=.278, \chi^{2}=144.776$, $p<.001)$, 구조함수를 기초로 하였을 때 부사 TNW (.826), 동사 $\mathrm{NDW}$ (.575), 형용사 TNW (.514), 감탄사 NDW (.338)가 연령 집단 을 구분하는 데 의미 있게 기여하는 것으로 나타났다. TTR 측정치 들로 판별분석한 결과에서도 종속측정치들이 연령 집단을 의미 있 게 판별해 주는 요인으로 확인되었으며(eigenvalue $=.877$, 정준상 관계수 $=.684$, Wilks의 $\left.\lambda=.316, \chi^{2}=129.701, p<.001\right)$ 동사(.645), 형용사(.607), 전체(.498), 명사.(412) 순서로 연령 집단을 확인하는 데 기여하는 것으로 나타났다.

\section{논의 및 결론}

본 연구는 초기 아동기에서 노년기까지 생애 전반에 걸친 어휘 사용 발달을 살펴보기 위하여 반구조화된 대화 절차를 통해 수집 된 50개 발화에서의 TNW, NDW, TTR을 측정하고 이를 중심으로 발달적 경향을 살펴보고자 하였다.

\section{전체 발화에서의 TNW, NDW, TTR}

먼저 전체 발화에서 연령 집단에 따른 TNW와 NDW는 연령 집
단에 따라 유의한 차이가 있었다. 사후분석 결과에서는 TNW와 $\mathrm{NDW}$ 모두 초기 아동기 집단이 후기 아동기 집단을 제외한 청소 년, 초기 성인기, 후기 성인기, 노년기 집단보다 유의하게 낮은 빈도 를 보였으며, 후기 아동기 집단도 청소년 집단보다 유의하게 적은 빈도를 보인 것으로 나타났다. 이러한 결과는 초기 아동기에서부터 노년기까지 TNW와 NDW 모두 꾸준히 증가하는 양상을 반영하 는데, 증가 정도가 아동기까지는 유의하지 않으나 청소년기 이후에 는 유의한 정도로 크게 증가하였음을 의미한다. 보통 자발화에서 의 어휘의 양적 발달은 취학전 아동기를 중심으로 보고되어 왔으 며, 대체로 연령 증가와 함께 어휘량도 증가한다고 보고되어 왔다 (Clark, 1995; Klee, 1992; Lee et al., 1980). 본 연구는 아동기는 물론 이후까지도 TNW나 NDW로 측정한 어휘의 양적 변화가 꾸준히 증가하였음을 보여주며, 특히 초기 아동기와 다른 발달기에는 이러 한 양적 변화가 통계적으로도 유의한 수준의 변화였음을 확인해 주었다.

본 연구에서는 청소년기에 TNW와 NDW가 제일 높았으며, 이 후 초기 성인기에 약간 감소한 후 노년기까지 유지되는 경향을 나 타냈다. 본 연구와 같이 발화 분석에서의 어휘량을 통한 보고는 아 니었지만 초기 성인기 이후부터 노년기까지도 어휘능력이나 어휘 사용량은 감소하지 않고 증가하거나 유지된다고 선행연구들 $(\mathrm{Kem}-$ per \& Sumner, 2001; Lindenberger \& Baltes, 1997)에서 보고된 바 있다. 본 연구는 대화를 통해서 수집된 언어 샘플에서도 성인기부 터 노년기까지 어휘 사용이 감소하거나 쇠퇴하지 않고 유지되는 경 향이 있음을 확인하였다.

연령 집단에 따라 증가 경향을 보인 TNW 및 $\mathrm{NDW}$ 와는 달리 TTR은 초기 아동기에는 .52 , 후기 아동기 .49 , 청소년기 .41로 점차 감소하였다가 초기 성인기와 후기 성인기에서 .44, 노년기 .46으로 다시 증가하는 경향을 보였다. TTR이 .50보다 높은 경우는 더 다양 한 어휘를 그리고 42 이하인 경우는 같은 낱말을 반복해서 사용하 
는 경향으로 이해되며(Owens, 2014), 영어권 자료이기는 하나 대체 로 2 세에서 8 세 사이의 아동들은 .42 에서 .50 사이의 TTR 수치를 보인다고 보고된 바 있다(Klee, 1992). 본 연구에서는 초기 아동기 .52 , 청소년기 .41을 제외하고는 Klee (1992)가 보고한 평균 범위에 속하는 것으로 나타났으며, 상대적으로 초기 아동기에는 사용하 는 어휘량이 많지는 않으나 대체로 다양한 어휘를 사용하는 것으 로 보이며, 청소년기에는 사용하는 어휘량이 많은 반면 같은 어휘 를 반복적으로 사용하는 것으로 이해할 수 있다.

\section{품사별 TNW, NDW, TTR}

품사별로 보았을 때, 모든 연령에서 전체 어휘 중 명사 TNW가 차지하는 비율이 $40 \%$ 이상으로 가장 높았으며, 그 다음으로는 동 사가 $27 \%-29 \%$, 그 다음으로는 부사가 $10 \%-13 \%$, 형용사가 $5 \%-10 \%$ 정도를 차지하였다. 그 외 다른 품사들은 $5 \%$ 미만의 낮은 사용 비 율을 보였다. 국내 연구에서 3 세에서 5 세 6 개월의 어린 아동들을 대상으로 한 Lee 등(1980)은 아동들이 전체 사용한 어휘 중 명사가 절반 가까이를 차지하였고, 동사를 $25 \%$ 내외, 부사를 $10 \%-12 \%$ 정 도 사용하였다는 본 연구와 거의 유사한 결과를 보고한 바 있다. 반 면, 대학생을 대상으로 한 Seo와 $\mathrm{Ku}$ (2005)는 명사가 가장 많은 비 중을 차지하였고, 그 다음으로 동사, 부사, 대명사, 형용사 순서로 어휘를 사용했다는 점은 유사하나, 명사 사용 비율이 $36.3 \%$ 동사 는 $18.6 \%$ 으로 약간 낮은 비율을, 반면 부사 $16 \%$, 대명사 $7.8 \%$ 로 더 높은 비율을 보고하였다. 본 연구는 동일한 절차를 통해 수집한 대 화 자료만을 분석하였으나, $\mathrm{Seo}$ 와 $\mathrm{Ku}$ (2005)는 토론 자료도 포함하 였으며, 분석 발화 수나 대학생만을 대상으로 하였다는 점 등에서 차이를 갖는다. 이러한차이가 수치에서의 차이를 가져왔을 수 있다.

연령 집단에 따른 품사별 TNW 차이 검정 결과에서는 대명사와 수사를 제외한 명사, 동사, 형용사, 부사, 관형사, 감탄사의 TNW에 서 유의한 차이가 있었다. 전체 발화에서의 TNW와 마찬가지로 초 기 아동기와 후기 아동기 집단이 청소년기 이후의 연령 집단에 비 해 대명사와수사를 제외한 모든 품사에서 유의하게 적은 TNW를 보였다. 또한 청소년 집단이 초기 성인기와 후기 성인기, 노년기 집 단과 각각 부사, 관형사, 감탄사를 유의하게 많이 사용하는 것으로 나타났다. 이러한 결과는 청소년기 이후 연령 집단이 초기 아동기 나 후기 아동기 집단에 비해 모든 품사에서 어휘 사용량이 많다는 것을 의미하며, 청소년기에는 특별히 부사와 관형사, 감탄사 사용 이 유의하게 많아진다는 것을 의미한다. 또한 명사, 동사, 형용사, 부 사는 초기 성인기에는 대체로 비슷하게 유지되다가 노년기에 약간 감소하는 경향을 보인 반면, 대명사는 초기 성인기에 감소하였다가 노년기에는 다시 증가하였으며, 관형사 사용도 큰 변화 없이 유지되
었다. 선행연구를 보면, 노년기에 들어서도 어휘 사용량은 감소하지 않고 증가 혹은 유지되나 낱말찾기에서의 어려움은 반복적으로 보 고된다(Burke \& Shafto, 2008). 낱말찾기에 어려움이 있는 경우 대 명사나 에두른 표현이 증가한다(Lee \& Kim, 2001, 2003). 본 연구 결과에서 노년기에 대명사나 관형사 사용 빈도가 증가한 것은 낱말 찾기 어려움으로 인한 것으로 해석해볼 수 있다.

품사별 NDW 역시 TNW와 마찬가지로 모든 연령에서 명사가 차지하는 비율이 $45 \%$ 이상으로 가장 높았으며, 그 다음으로는 동 사가 20\%-25\%로 그 다음으로는 부사가 $10 \%-14 \%$, 형용사가 6\%$10 \%$ 정도를 차지하였으며, 그 외 다른 품사들은 $5 \%$ 미만의 낮은 사 용 비율을 보여 대체로 TNW와 유사하였다. 이 역시 초기 아동기 를 대상으로 한 Lee 등(1980)의 연구와는 유사하나 대학생을 대상 으로 한 Seo와 $\mathrm{Ku}$ (2005)와는 약간 차이가 있다. Seo와 $\mathrm{Ku}(2005)$ 는 명사는 $65 \%$, 동사는 $13.2 \%$ 로 명사 $\mathrm{NDW}$ 는 더 높게, 동사 $\mathrm{NDW}$ 는 낮게 보고하였다. 반면, 부사는 $9 \%$, 형용사는 $6.7 \%$ 로 본 연구와 큰 차이가 없었다. 이 역시 언어 샘플의 효과나 대상자 요인이 미치 는 영향에 대한 시사점을 제공한다.

연령 집단에 따른 $\mathrm{NDW}$ 의 차이를 검정한 결과에서는 $\mathrm{TNW}$ 와 마찬가지로 대명사와 수사를 제외한 명사, 동사, 형용사, 부사, 관형 사, 감탄사에서 유의한 차이가 있었다. 사후분석 결과, 초기 아동기 와 후기 아동기 집단이 청소년기 이후의 연령 집단들과 수사와 대 명사를 제외한 모든 품사에서 NDW가 많으며, 청소년 집단이 이후 연령 집단들에 비해 관형사와 감탄사 $\mathrm{NDW}$ 가 유의하게 많은 것으 로 나타났다. 이러한 결과는 TNW와 마찬가지로 NDW도 청소년 기 이후 연령 집단이 초기 아동기나 후기 아동기 집단에 비해 모든 품사에서 새로운 어휘를 많이 표현하며, 청소년기에는 사용하는 관형사와 감탄사가 다양하다는 것을 의미한다. Figure 2 를 보면 대 체로 대명사를 제외한 모든 품사의 NDW는 TNW에 비해 집단 간 에 빈도 차이는 적은 반면 그래프는 비슷한 경향으로 변화하는 것 으로 나타났다. 반면 대명사의 경우는 TNW는 청소년과 노인 집단 에서 비슷한수준으로 가장 높은 빈도를 보였으나, NDW는 아동집 단에서 가장 높은 빈도를 보이고 이후 노인 집단까지 서서히 감소 하는 경향을 보였다. 이는 청소년기와 노년기에는 소수의 대명사를 반복적으로 사용하는 경향을 보여 주는 것으로 TNW 결과와 더불 어 대명사 사용이 연령에 따른 변화를 보여줄 수 있음을 시사한다.

품사별 TTR은 .15-85 범위로 나타났다. 연령 집단에 따른 차이 를 검정한 결과, 수사를 제외한 명사, 대명사, 동사, 형용사, 부사, 관 형사, 감탄사에서 유의한 차이를 보였으며, 대체로 초기 아동기와 후기 아동기, 후기 성인기와 노년기에 비해 청소년과 초기 성인기 집단의 TTR이 유의하게 낮았기 때문에 나타난 것으로 확인되었 
다. 기술통계를 보면, 초기 아동기와 후기 아동기 집단에서는 대부 분이 .5 이상 높은 TTR을 보인 반면, 청소년과 초기 성인기 집단은 절반의 품사에서 .4 이하를 보여 대체로 낮은 TTR을 보였다. TNW 와 NDW 수치를 함께 고려할 때, 초기 아동기와 후기 아동기 TTR 이 상대적으로 높은 것은 이 시기가 전반적인 어휘 사용량이 많지 않은 반면, 언어발달이 상대적으로 급속하게 이루어지는 시기이기 때문에 새롭게 습득하는 어휘가 많아서 높은 TTR이 산출된 것으 로 보인다. 반면, 청소년기 이후에도 계속 새로운 어휘를 습득하기 는 하지만, 상대적으로 일상 중에 사용하는 낱말, 즉 $\mathrm{TNW}$ 가 많기 때문에 TTR은 상대적으로 낮아지는 것으로 해석된다.

품사에 따라서는 대체로 모든 연령 집단이 명사는 48 이상의 높 은 TTR을 보였고, 동사는 청소년부터 노인까지 .40이하의 낮은 TTR을 보였다. TNW와 NDW의 결과와 종합하여 해석할 때, 모든 연령 집단이 명사를 가장 많이 사용할 뿐만 아니라 가장 다양하게 사용한다고 볼 수 있다. 반면, 동사의 경우는 많이 사용하기는 하지 만 같은 어휘를 반복적으로 사용하는 경향이 크며, 특히 이러한 경 향은 후기 성인기와 노년기에서 두드러지는 것으로 해석할 수 있다. 그 외, 수사는 후기 성인기 집단을 제외한 모든 연령 집단에서 매우 낮은 TTR을 보였는데, 이는 수사가 한정되어 있기 때문으로 보이 며, 특히 초기 아동기 집단에서 수사 TTR .15로 가장 낮았는데 이 는 아동들이 수에 대한 개념 부족으로 제한된 수사만을 반복적으 로 사용하였기 때문으로 해석된다.

\section{연령 집단 판별 요인}

마지막으로 TNW와 NDW, TTR 중 연령 집단을 가장 잘 판별할 수 있는 종속측정치를 확인하기 위하여 집단 간에 차이가 있는 측 정치를 투입하여 판별분석을 실시한 결과, TNW와 $\mathrm{NDW}$ 중에서 는 부사 TNW, 동사 NDW, 형용사 TNW, 감탄사 NDW가 연령 집 단을 구분하는 데 의미 있게 기여하는 것으로 나타났으며, TTR 중 에서는 동사, 형용사, 전체, 명사 순서로 연령 집단을 확인하는 데 기여하는 것으로 나타났다. 즉, 이 측정치들을 기초로 연령 집단을 분류할 때 의미 있게 분류할 수 있다는 것을 의미한다. 연령 집단을 분류하는 데 기여하는 것으로 나타난 측정치들을 살펴보면, Tables 4-6에 나타난 것과 같이 부사 TNW, 형용사 TNW, 동사 NDW, 감 탄사 NDW는 청소년기까지 증가하다가 노년기로 갈수록 다소 감 소하지만 증가된 형태를 유지하는 것으로 나타났고, 동사, 형용사, 전체, 명사의 TTR은 대체로 연령이 증가하면서 사용하는 어휘는 많아지지만 사용하는 어휘 수에 비해 어휘다양도는 어린 연령에서 더 높게 나타났다. 그러나 투입한 측정치들의 수에 비하여 사례 수 가 충분하지 않고, 통계치 중에서 판별함수의 설명력을 나타내는 고유값(eigenvalue)이 작으므로 결과를 해석하는 데 유의해야 한다. 본 연구를 통해 초기 아동기부터 노년기까지 어휘 사용의 발달 을 살펴본 결과, 전체 TNW와 NDW는 연령이 증가함에 따라 증가 하였으며, 특히 초기 아동기에서 청소년기까지 유의하게 증가하였 고, 유의한 수준은 아니었으나 청소년기 이후에는 감소한 후 성인 기부터 노년기까지는 비슷하게 유지되었음을 확인하였다. 품사별 TNW와 NDW는 품사에 따라 차이가 있었으나 대체로 NDW에 비 해 TNW에서 연령에 따른 변화가 컸다. 대체로 노년기에 사용이 증 가한 것으로 나타난 대명사와 수사를 제외하고는 다른 모든 품사 는 청소년기까지는 증가하는 양상을 보였으며, 노년기까지는 유지 혹은 약간 감소하는 경향을 보였다.

$\mathrm{TNW}$ 와 NDW가 연령에 따라 증가하였다가 유지 혹은 감소하 는 경향을 보인 것과는 다르게 TTR은 연령이 증가함에 따라 감소 하였다가 증가하는 경향을 보였다. 초기 아동기와 후기 아동기는 각각 .52 와 . 49 의 대체로 높은 수치를 보인 반면, 청소년기에는 .41 로 가장 낮았고, 초기 성인기와 후기 성인기는 각각 .44로 증가하기 시작하여 노년기에는 .46의 TTR을 보였다. 이러한 경향은 품사별 TTR에서도 비슷하게 반영되었다.

본 연구는 특정 연령에 국한하지 않고 초기 아동기에서 노년기까 지 어휘 사용에서의 발달 경향을 전생애적인 관점에서 파악하였다 는 점에서 의의가 있다. 또한 어휘 사용이 발화 자료 수집 조건이나 자료에 의해 영향을 받을 수 있음을 고려하여 동일한 절차를 통해 발화 자료 수집으로 인한 영향을 최소화하였다는 점에서도 의의 를 찾을 수 있다. 반면, 생애 발달 주기를 6개의 발달 시기로 구분하 여 살펴보았기 때문에 연속적인 과정을 세세하게 설명하기에는 미 흡함이 있으며, 성별이나 기타 개인적 요인들을 고려하지 못하였다 는 점도 제한점으로 고려할 수 있다. 생애 전반에 걸친 언어발달 연 구의 필요성을 확인하였다는 점에서 의의를 두며 추후 이 연구의 제한점을 보완한 후속 연구가 지속되기를 희망한다.

\section{REFERENCES}

Ardila, A., \& Rosselli, M. (1996). Spontaneous language production and aging: sex and educational effects. International Journal of Neuroscience, 87, 71-78.

Baltes, P. B. (1987). Theoretical propositions of life-span developmental psychology: on the dynamics between growth and decline. Developmental Psychology, 23, 611-626.

Burke, D. M., \& Shafto, M. A. (2008). Language and aging. The Handbook of Aging and Cognition, 3, 373-443. 
Carey, S. (1978). The child as word learner. In M. Halle et al. (Eds.), Linguistic theory and psychological reality (pp. 264-293). Cambridge, MA: MIT Press.

Chang, K. H, \& Jeon, E. J. (2008). A study on the diversity of words used by middle and high school students. Korean Semantics, 27, 225-242.

Christensen, K. J., Multhaup, K. S., Nordstrom, S., \& Voss, K. (1991). A cognitive battery for dementia: development and measurement characteristics. Psychological Assessment: A Journal of Consulting and Clinical Psychology, 3, 168-174.

Clark, E. V. (1995). Later lexical development and word formation. In P. Fletcher \& B. MacWhinney (Eds.), The handbook of child language (pp. 393412). Oxford: Blackwell Publishers.

De Bot, K., \& Schrauf, R. W. (2010). Language development over the lifespan. New York, NY: Routledge.

Gerstenberg, A., \& Voeste, A. (2015). Investigating the lifespan perspective. Language Development: The Lifespan Perspective, 37, 1-8.

Havighurst, R. J. (1973). History of developmental psychology: socialization and personality development through the life span. In P. B. Baltes \& K. W. Schaie (Eds.), Life-span developmental psychology (pp. 3-24). New York, NY: Academic Press.

Hwang, S. T., Kim, J. H., Park, K. B., Choi, J. Y., \& Hong, S. H. (2012). KoreanWechsler Adult Intelligence Scale IV (K-WAIS-IV). Daegu: Korea Psychology Co.

Kang, Y. (2006). A normative study of the Korean-Mini Mental State Examination (K-MMSE) in the elderly. Korean Journal of Psychology: General, $25,1-12$.

Kemper, S., \& Sumner, A. (2001). The structure of verbal abilities in young and older adults. Psychology and Aging, 16, 312-322.

Kemper, S., Kynette, D., Rash, S., O’Brien, K., \& Sprott, R. (1989). Life-span changes to adults' language: effects of memory and genre. Applied Psycholinguistics, 10, 49-66.

Kemper, S., Thompson, M., \& Marquis, J. (2001). Longitudinal change in language production: effects of aging and dementia on grammatical complexity and semantic content. Psychology and Aging, 16, 600-614.

Kim, Y. T., Hong, G. H., Kim, K. H., Jang, H. S., \& Lee, J. Y. (2009). Receptive \& expressive vocabulary test (REVT). Seoul: Seoul Community Rehabilitation Center.

Klee, T. (1992). Developmental and diagnostic characteristics of quantitative measures of children's language production. Topics in Language Disorders,
12, 28-41.

Lee, H. J., \& Kim, J. P. (2004). An analysis of vocabulary in storybooks for preschool children. Korean Journal of Communication \& Disorders, 9, 5777.

Lee, Y. M., \& Kim, H. (2001). An utterance analysis of conversations and picture description tasks of Korean adults. Korean Journal of Communication ¿ Disorders, 6, 40-52.

Lee, Y. S., Kwon, K. A., \& Jung, I. S. (1980). The study of Korean children's vocabulary development 1. Seoul: Korean Educational Development Institute.

Lee, Y., \& Choi, J. (in press). Hallym Conversation and Pragmatic Assessment Protocol. Manuscript in preparation.

Lee, Y., \& Kim, Y. T. (2003). Word (noun and verb) production in children with specific language impairment. Korean Journal of Communication \& Disorders, 8, 1-19.

Lindenberger, U., \& Baltes, P. B. (1997). Intellectual functioning in old and very old age: cross-sectional results from the Berlin Aging Study. Psychology and Aging, 12, 410-432.

Nagy, W. E., \& Anderson, R. C. (1984). How many words are there in printed school English? Reading Research Quarterly, 19, 304-330.

Nippold, M. A. (2000). Language development during the adolescent years: aspects of pragmatics, syntax, and semantics. Topics in Language Disorders, 20, 15-28.

Nippold, M. A. (2007). Later language development: school-age children, adolescents, and young adults. Austin, TX: Pro-Ed.

Nippold, M. A., \& Duthie, J. K. (2003). Mental imagery and idiom comprehension: a comparison of school-age children and adults. Journal of Speech, Language, and Hearing Research, 46, 788-799.

Nippold, M. A., \& Sun, L. (2008). Knowledge of morphologically complex words: a developmental study of older children and young adolescents. Language, Speech, and Hearing Services in Schools, 39, 365-373.

Nippold, M. A., Ward-Lonergan, J. M., \& Fanning, J. L. (2005). Persuasive writing in children, adolescents, and adults: a study of syntactic, semantic, and pragmatic development. Language, Speech, and Hearing Services in Schools, 36, 125-138.

Owens, R. E. (2014). Language disorder: a functional approach to assessment and intervention (6th ed.). Boston, MA: Pearson.

Seo, S. K., \& Ku, H. J. (2005). Korean spoken corpus (2): based on college student conversation corpus. Seoul: Hankukmunwhasa. 


\section{국문초록}

\section{초기 아동기(유아기)에서 노년기까지 전생애 어휘 사용 발달: 대화 자료 분석을 중심으로}

이윤경 $\cdot$ 최지은 ${ }^{2} \cdot$ 윤지혜 ${ }^{\prime} \cdot$ 김유섭 ${ }^{3} \cdot$ 민준상 ${ }^{2} \cdot$ 김지수 ${ }^{3}$

'한림대학교 언어청각학부, ${ }^{2}$ 한림대학교 대학원 언어병리청각학과, ${ }^{3}$ 한림대학교 융합소프트웨어학과

배경 및 목적: 본 연구는 초기 아동기에서 노년기까지 생애 전반에 걸친 어휘 사용 발달을 살펴보는 것을 목적으로 하였다. 방법: 연구 참가자는 초기 아동기, 후기 아동기, 청소년, 초기 성인기, 후기 성인기, 노년기 각각 20 명씩, 총 120 명이었다. 연구 참가자를 대상으로 정 해진 절차에 따라 대화자료를 수집하였으며, 수집된 자료 중에서 50 개의 발화를 발췌하여 전체 및 품사별 TNW, NDW, TTR을 측정하 였다. 결과: 전체 TNW와 NDW 모두 초기 아동기에서 청소년기까지는 증가하였으나, 초기 성인기에 감소한 후 노년기까지 비슷하게 유 지되었으며, TTR은 청소년기까지는 서서히 감소하다가 초기 성인기에 약간 증가하여 노년기까지 비슷하게 유지되었다. 품사별 TNW와 $\mathrm{NDW}$ 모두 초기 아동기부터 청소년기까지 유의하게 증가하였다. 명사, 동사, 부사, 형용사 TNW와 NDW는 초기 성인기에 약간 감소한 후 노년기까지 비슷하게 유지되거나 감소하였으나, 대명사 TNW는 장년기와 노년기에 점차 증가하였으며, 수사 TNW와 NDW도 장년 기와 노년기에 증가하였다. 품사별 TTR은 유아와 아동 집단에서는 대부분이 .5 이상 높은 TTR을 보인 반면 청소년과 젊은 성인 집단은 절반의 품사에서 .4이하를 보여 대체로 낮은 TTR을 보였다. 판별분석 결과 부사 TNW, 동사 NDW, 형용사 TNW, 감탄사 NDW이 연 령 집단을 잘 판별해주는 요인으로 나타났다. 논의 및 결론: 본 연구결과는 어휘 사용에서의 생애 전반에 걸친 변화를 이해하도록 하 며, 언어 평가나 중재에 활용할수 있을 것이다.

핵심어: 전생애 언어발달, 어휘 발달, 낱말 사용, TNW, NDW, TTR, 어휘다양도

이 논문은 2017년도 한림 선도연구그룹지원사업(No. HRF-LGR-2017-0002)의 지원을 받아 연구되었음.

본 논문의 자료 수집과 자료 분석에 참여한 양예원, 오승아, 최진주, 홍원경 한림대학교 대학원생에게 감사드립니다.

\section{참고문헌}

강연욱(2006). K-MMSE (Korean-Mini Mental State Examination)의 노인 규준 연구. 한국심리학회지: 일반, 25, 1-12.

김영태, 홍경훈, 김경희, 장혜성, 이주연(2009). 수용표현어휘력검사(REVT). 서울: 서울장애인종합복지관.

서상규, 구현정(2005). 한국어 구어 연구(2): 대학생 대화 말뭉치를 중심으로. 서울: 한국문화사.

이연섭, 권경안, 정인실(1980). 한국 아동의 어휘발달 연구(I). 서울: 한국교육개발원.

이영미, 김향희(2001). 대화와 그림설명과제를 통한 한국성인 발화의 비교 분석. 언어청각장애연구, 6, 1-11.

이윤경, 김영태(2003). 단순언어장애아동의 낱말산출능력: 명사와 동사를 중심으로. 언어청각장애연구, 8, 1-19.

이희진, 김주필(2004). 유아용 동화책의 어휘 분석 연구. 언어청각장애연구, 9, 57-77.

장경희, 전은진(2008). 중·고등학생의 어휘 다양도 연구. 한국어 의미학, 27, 225-242.

황순택, 김지혜, 박광배, 최진영, 홍상황(2012). 한국판 웩슬러 성인용 지능검사 4 판(K-WAIS-IV). 대구: 한국심리주식회사. 